\title{
RESEARCH TOOLS APLICABLE IN DESIGNING OF HIGH-SPEED AND HIGH-POWER RAIL VEHICLES
}

\author{
VoJTĚCH DYBALA
}

\begin{abstract}
Czech Technical University in Prague, Faculty of Mechanical Engineering, Department of Automotive, Combustion Engines and Railway Engineering, Technická 4, Prague, Czech Republic

correspondence: Vojtech.Dybala@fs.cvut.cz
\end{abstract}

\begin{abstract}
The importance of the railway transport of both goods and passengers continuously grows as it is in many points of view more ecological and economical solution in comparison with road transport. Just the importance has been supporting efforts to design more powerful and faster trains reaching traction powers more than 1.6 MW per a wheel-set or service top speed much more than 300 $\mathrm{km} / \mathrm{h}$ till these days. To reach design which has enabled such a kind of performances it was necessary to research dynamic behaviour of railway vehicles. Both via laboratory measurements and simulations. The laboratory experiments have been carried out on a specially designed laboratory equipment called roller rigs. A laboratory equipped by roller rig for testing of the railway vehicle dynamic behaviour has been built at the Faculty of Mechanical Engineering at CTU in Prague, also within PhD study programs and SGS grants. Another powerful tool within research activities is a simulation. Kind of a such simulation will be presented by this contribution with the focus on the torsion dynamics of high-power fully-suspended drive of a railway vehicle, which has been developed also by $\mathrm{PhD}$ students under financial support of The Faculty of Mechanical Engineering and related grants.
\end{abstract}

KEYWORDS: Railway vehicle, dynamic, roller rig, rollers, drive, torsion dynamics.

\section{INTRODUCTION}

In the railway vehicle's research has been used different tools. These are calculations and simulations carried out via specialized software, measurements on real vehicles on real tracks and measurements carried out in laboratories on roller rigs. The importance of roller rigs comes just from laboratory conditions and its advantages. The possibility to define exact conditions of measurements, ability to reproduce measurements, research of dangerous phenomena and low costs against measurements on real vehicles on real tracks. All of this caused from the $2^{\text {nd }}$ half of the $20^{t h}$ century till these days an expansion of roller rigs in connection with the need to research dynamic behaviour of railway vehicles. Whereas roller rigs were built for base research there has been also a need to do an applied research on the engineering level via simulations in the industry. For these purposes various software has been developed and used. The university setting enables to apply both approaches for $\mathrm{PhD}$ students, however its limited in comparison with industry companies and specialized research centres. Nevertheless, applicability of roller rigs and simulation results of torsion oscillations and their excitation were achieved.

\section{Roller RigS}

The roller rig is a device, which consists of three main parts. These are a frame or an external construction of the roller rig, rollers and a propulsion system of rollers with related components as e.g. couplings and shafts. The most important are the rollers as these components shall simulate rails as a part of the railway infrastructure. The rollers simulating endless rails can be of two basic design types, as applied for roller rigs at CTU in Prague:

- Disc type rollers - Figure 1 left,

- Drum type rollers - Figure 1 right, which is a prototype roller

From the historical point of view roller rigs touches the remote past. For example [1], Figure 2 presents the roller rig from Swindon in England specified to measure a traction power of steam locomotives.

Another example of a roller rig, which was built in the real-life scale, can be the workplace created in 1977 by Deutsche Bahn AG in Munich, see [1, 2] and Figure 3 This research workplace was dedicated for the research and development of the first generation of ICE high-speed train. This device enabled to research train dynamic behaviour on its limits under different conditions - speeding in the straight track, acceleration and braking behaviour or ride on a track with deviated geometry etc. Except of these big real-life scale devices reduced scale devices have been created. In this area the scaled roller rigs, which has been built at the Faculty of Mechanical Engineering at CTU in Prague, see Figure 4 and Figure 5, can be taken as examples. The first roller rig has been used for the education and its abilities and continuous development were presented [3, 4]. Student's measurements are focused on the transverse dynamic of railway bogie movements within the education. 

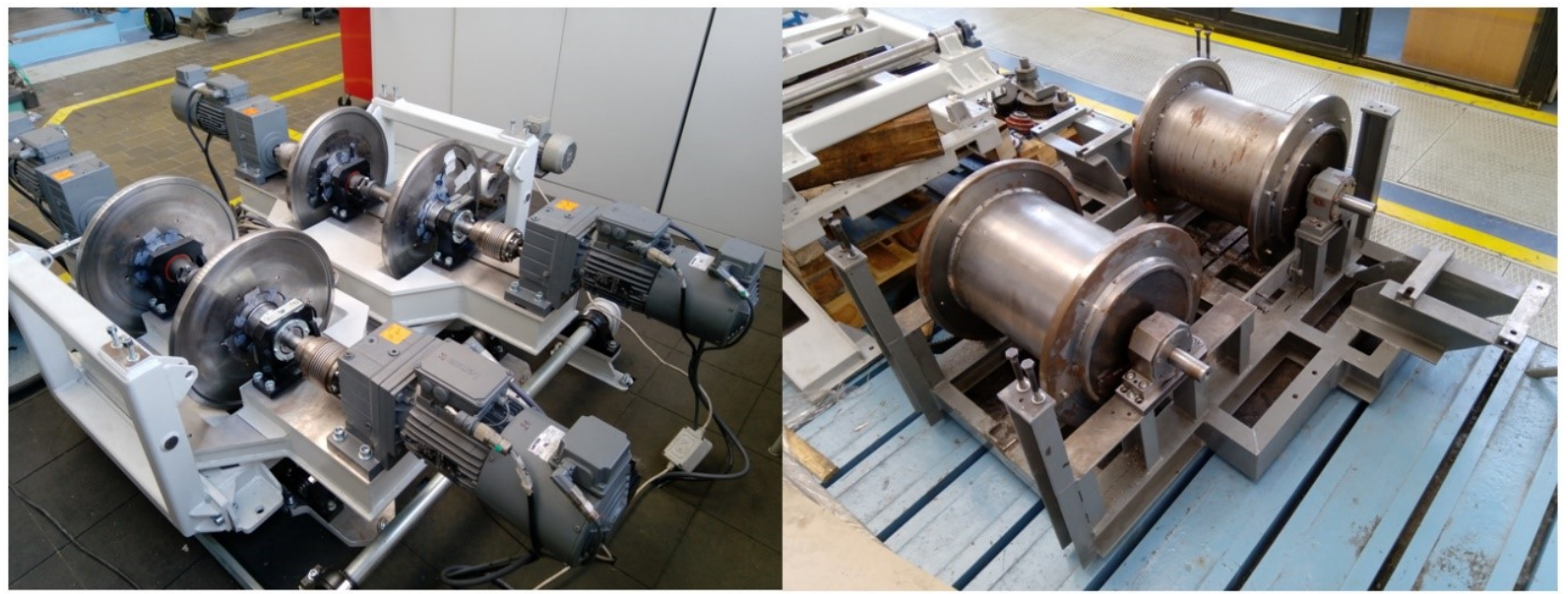

Figure 1. Roller rigs - Faculty of Mechanical Engineering at CTU in Prague.

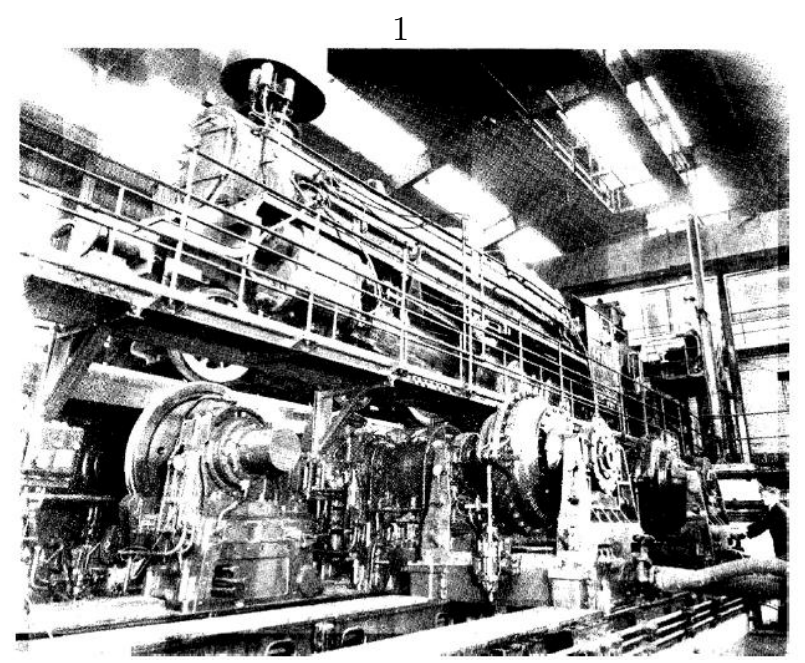

Figure 2. The roller rig in Swindon [1].

The second roller rig has been under construction and without a practical used till these days. Its purpose is generally oriented into torsion dynamics and for first attempts to measure the adhesion phenomena in the wheel-roller contact as a simulation of the wheel-rail contact, which we know from numbers of measurements. As a good example can be used results presented in [5] and Figure 6.

The basic idea for the supposed measurements of the adhesion coefficient comes from the picture of forces, which act in the wheel-rail contact as presented in [7] and Figure 7 and the knowledge, that the adhesion coefficient is a function of a wheel slip. According to the Equation (1) the tangential force $T_{1}$, which is an equivalent of the wheel torque and vertical wheel force $Q$ will be measured and adhesion coefficient $\mu$ will be calculated.

$$
T_{1}=Q \mu
$$

As the adhesion coefficient is a function of the wheel slip, the slip itself will be calculated based on the difference in rotation speed of a wheel-set and a roller, which will be measured. On the real vehicle the slip is defined based on the difference of the vehicle speed and real rotation speed of a wheel-set. This fact is defined by the equation (2) and its deduction in [7] and Figure 8

$$
s=\frac{r_{K} \omega_{K}-v}{v}
$$

\section{Torsion Oscillations Research}

Within a generally defined task to research transition and electromechanical phenomena in traction drives of railway vehicles, the phenomenon of torsion oscillations has been researched as well. The torsion oscillation problems were studied also in the past, which is documented in [5]. That contribution presents results from simulations of the torsion dynamics for the mathematical model of the experimental roller rig with different types of wheelset drives. This contribution deals with torsion dynamics and oscillations, which are excited by harmonic components of the traction motor electromagnetic torque. The intended simulation model, which was created in MATLAB Simulink, utilizes the idea, that the railway vehicle can be simplified into three basic separate sub-models from the perspective of the drive system. These are the electrical part, the mechanical part and the wheel-rail contact part, as shown in [8] and Figure 9 Fundamentals and function descriptions of the model as a whole were published in [7-9] and therefore no attention will be payed to them. The intention of this contribution is to present results of simulations focused on the oscillations.

The phenomenon of torsion oscillations has been researched via a mathematical model which is equivalent to a fully-sprung mechanical drive of a locomotive, see [7] and Figure 10. For the simulation model the drive has been reduced into a schematic torsion system as presented in Figure 11 .

Particular rotation masses, defined by their mass of inertia $J_{x}$ and torsion springs between them, defined 

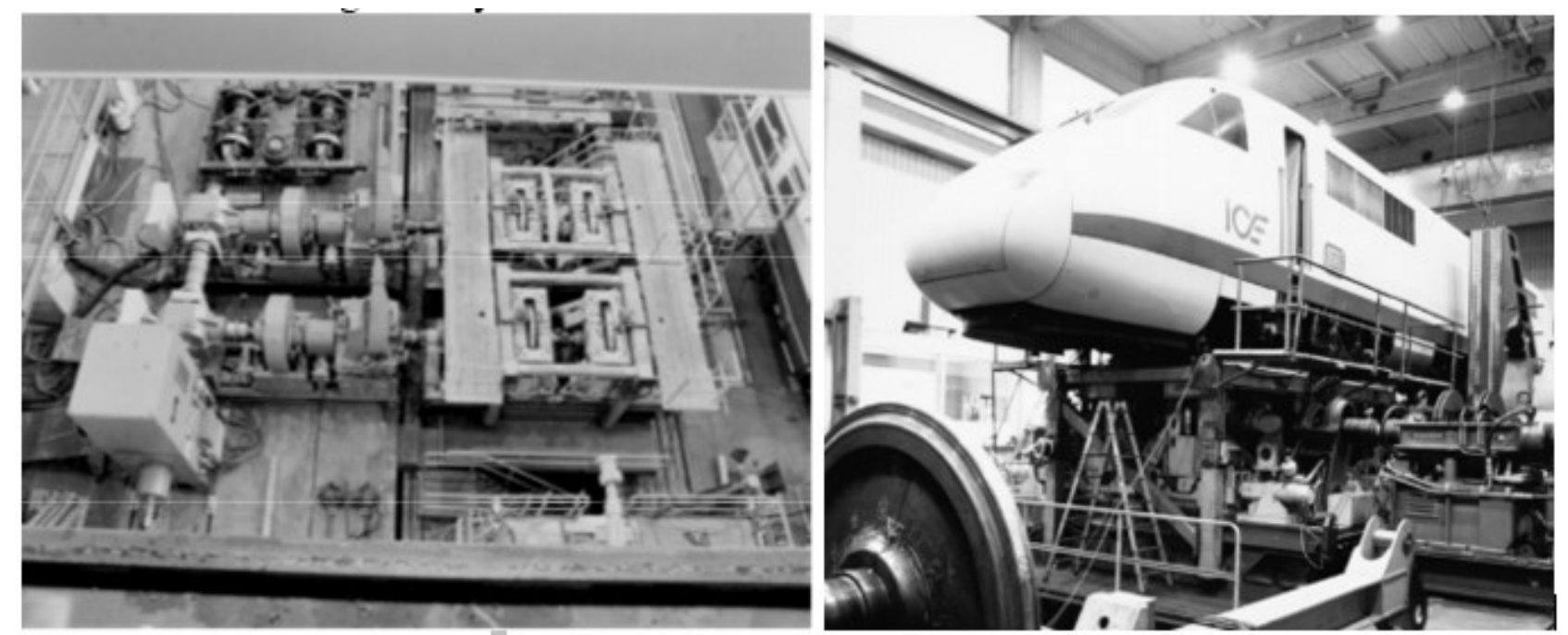

Figure 3. The roller rig built by DB-AG in Munich [1, 2].

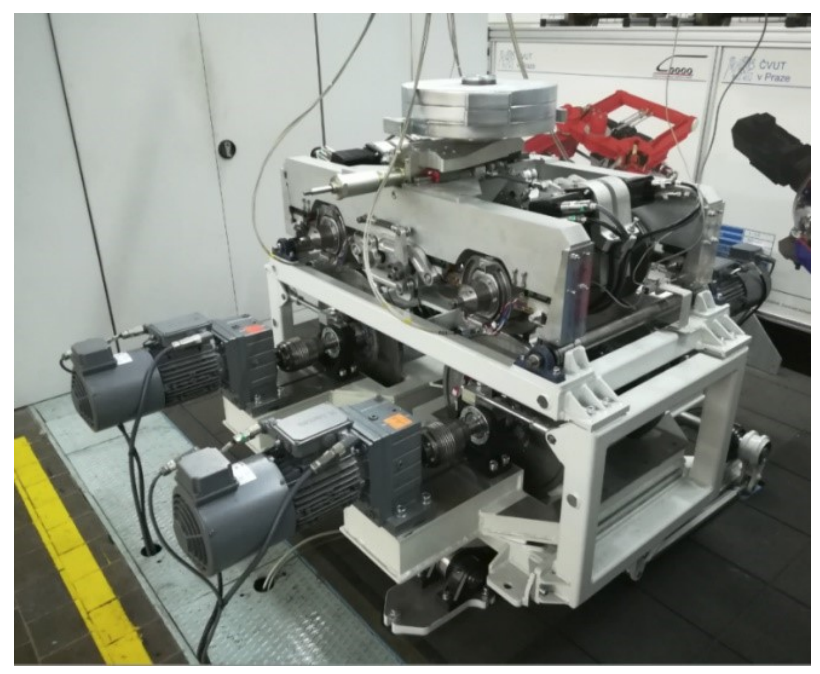

Figure 4. The roller rig - Faculty of Mechanical Engineering at CTU in Prague.

by their torsion stiffness $k_{x}$ are mathematically represented within the simulation model like in [7] and Figure 12

The electromagnetic torque $M$ produced by the asynchronous motor model, which accelerates whole model of the railway vehicle, is the source of excitation of the oscillations in the torsion system, because it consists of a nominal value and superimposed harmonic components. The course of this rippled torque within a simulation can be seen in Figure 13 Fast Fourier Transformation (FFT) of the electromagnetic torque in Figure 14 revealed harmonic components with typical frequencies. These harmonic components interact with the mechanical system in such a way, that they excite the oscillations.

Simulations proved, that excited oscillations can reach significant magnitudes for oscillation frequencies, which are the natural frequencies of the mechanical system. As in this simulation case dominant oscillations for frequencies around $2400 \mathrm{~Hz}$ appeared in

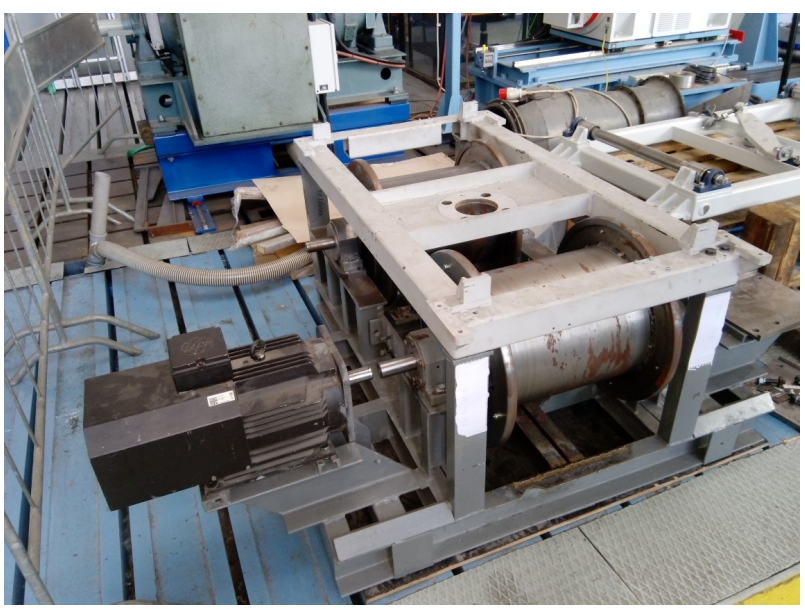

Figure 5. The roller rig - Faculty of Mechanical Engineering at CTU in Prague.

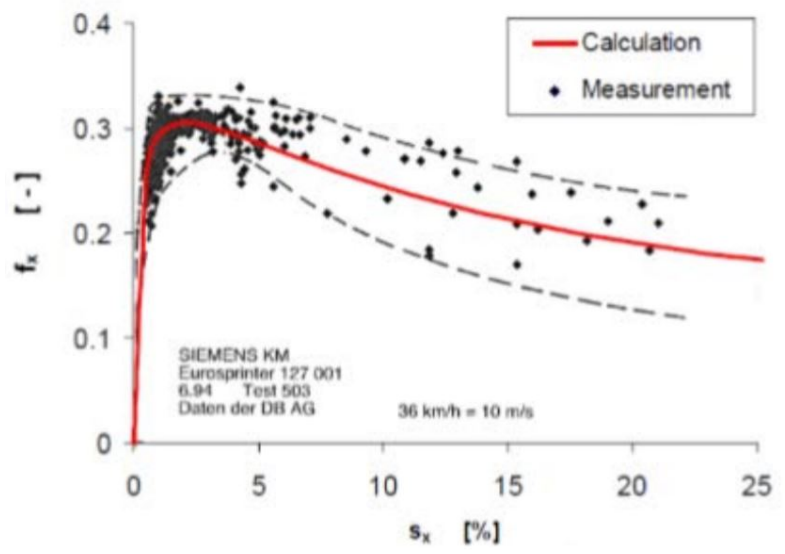

Figure 6. Comparison of measured and calculated coefficient of adhesion [6].

FFT in gear's acceleration torques, the example for the gearwheel acceleration torque course is shown in Figure 15 and Figure 16.

Table 2 shows that the magnitude of harmonic 


\begin{tabular}{lll}
\hline $\begin{array}{l}\text { Harmonic } \\
\text { frequency } \\
{[\mathrm{Hz}]}\end{array}$ & $\begin{array}{l}\text { Harmonic component magnitude in relation to nominal } \\
\text { value of signal }[\%]\end{array}$ & Phenomenon description \\
\hline 137 & 106 & $\begin{array}{l}3^{\text {rd }} \text { multiple of } 1^{\text {st }} \text { harmonic of } \\
\text { motor supply voltage }\end{array}$ \\
\hline $\begin{array}{l}800 \text { and its } \\
\text { multiples }\end{array}$ & 10 to 55 & $\begin{array}{l}\text { even and odd multiples of inverter } \\
\text { switching frequency }\end{array}$ \\
\hline$+/-137$ & 0 to 8 & $\begin{array}{l}\text { side bands of switching frequency } \\
\text { multiples }\end{array}$ \\
\hline
\end{tabular}

TABLE 1. Harmonic frequencies of electromagnetic torque - overview and description.

\begin{tabular}{lll}
\hline $\begin{array}{l}\text { Harmonic } \\
\text { frequency } \\
{[\mathrm{Hz}]}\end{array}$ & $\begin{array}{l}\text { Magnitude of harmonic component in relation to nominal } \\
\text { value of signal }[\%]\end{array}$ & Phenomenon description \\
\hline 2400 & 105 & $\begin{array}{l}3^{\text {rd }} \text { multiple of inverter switching } \\
\text { frequency }\end{array}$ \\
\hline 2401 & 185 & $\begin{array}{l}7^{\text {th }} \text { natural frequency of the me- } \\
\text { chanical system }\end{array}$ \\
\hline
\end{tabular}

TABLE 2. Harmonic frequencies of the gearwheel accelerating torque - overview and description.

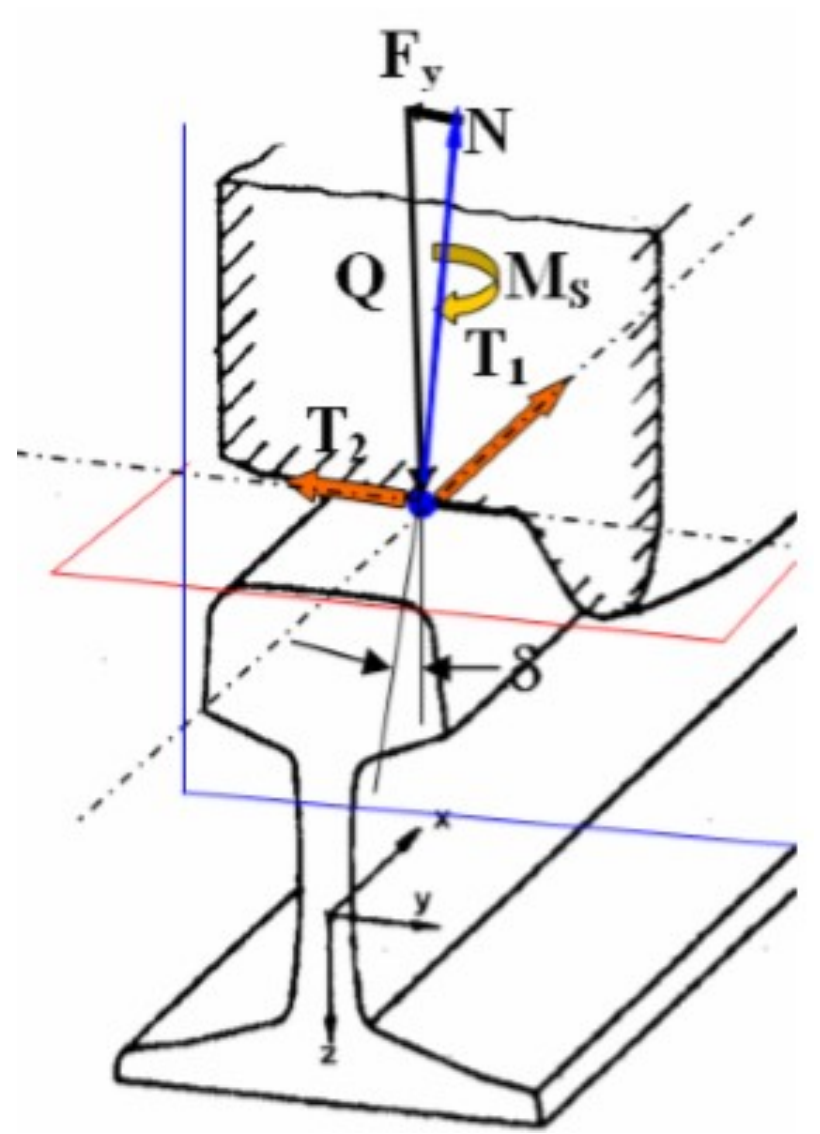

FIgURE 7. Wheel-rail contact forces [7].

components of the rippled torque can be significantly higher than nominal value of the torque. In presented case $85 \%$ higher for the frequency of $2401 \mathrm{~Hz}$. This behavior is caused by the fact, that the $3^{\text {rd }}$ multiple of the inverter switching frequency $2400 \mathrm{~Hz}$ contained in the electromagnetic torque, which excites system's oscillation, is close to $7^{\text {th }}$ natural frequency of the

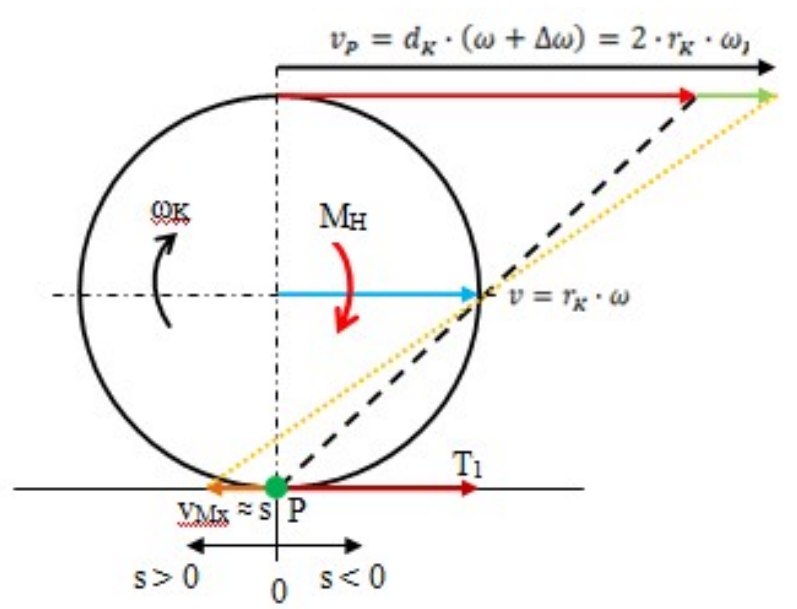

Figure 8. Wheel slip deduction [].

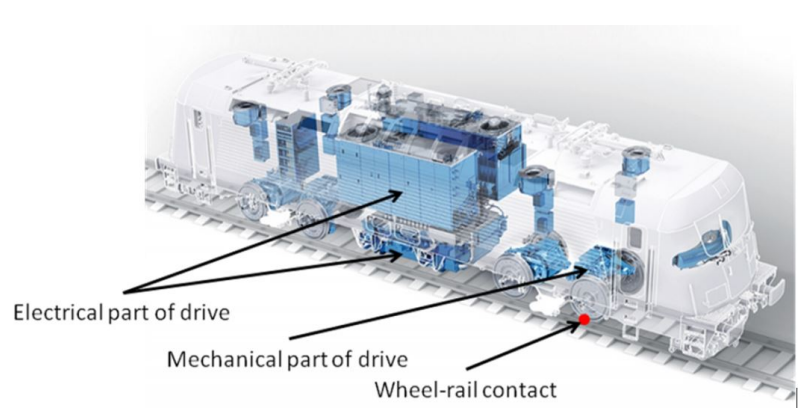

Figure 9. Visualization of fundamental model parts 8].

mechanical system $\approx 2401 \mathrm{~Hz}$.

\section{Conclusions}

With respect to the roller rigs as research and education tools at The Faculty of Mechanical Engineering, CTU in Prague the intention is to build the roller rig, which will enable to realize measurements of adhesion 


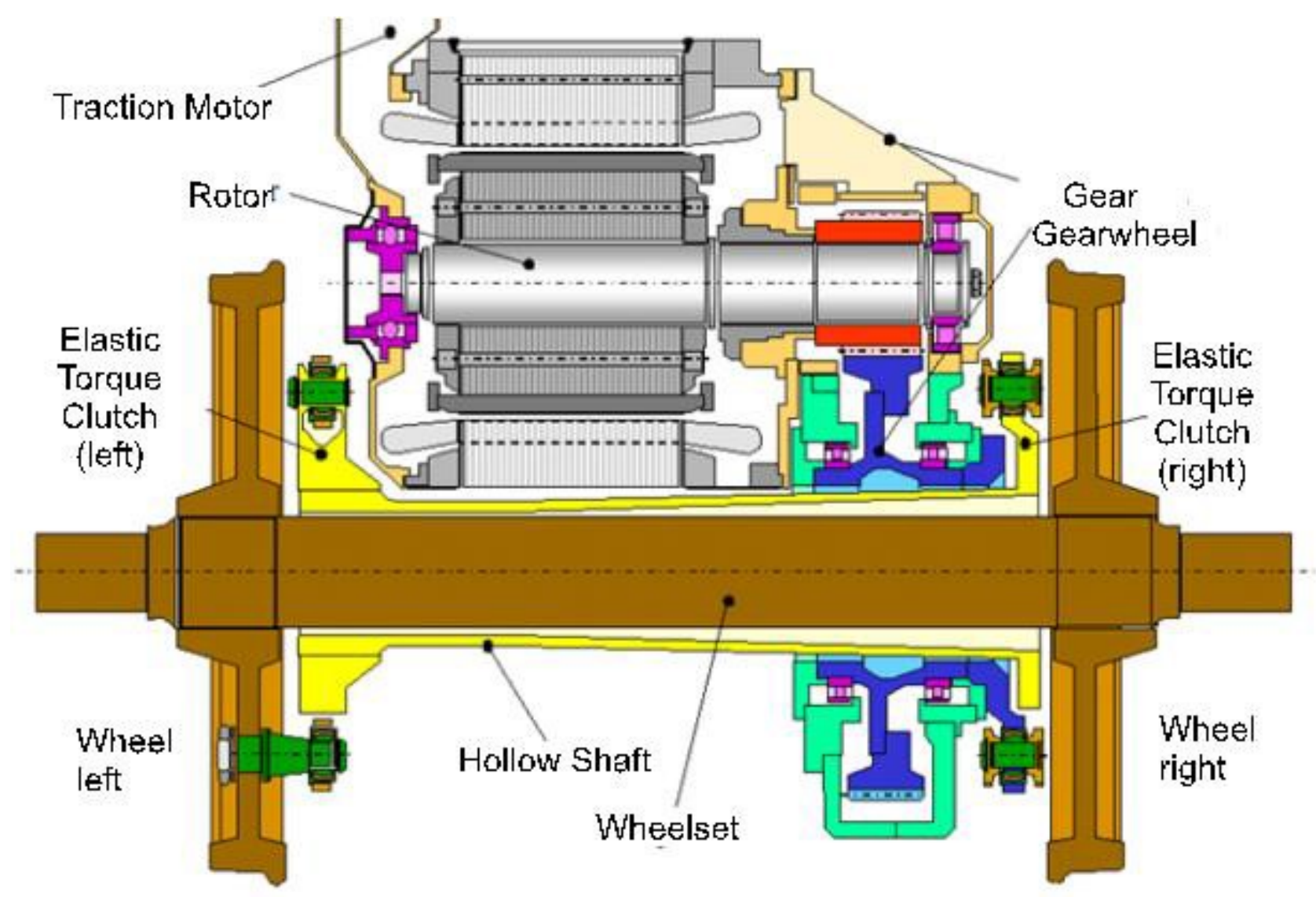

Figure 10. Locomotive fully-sprung drive - cross section [7].

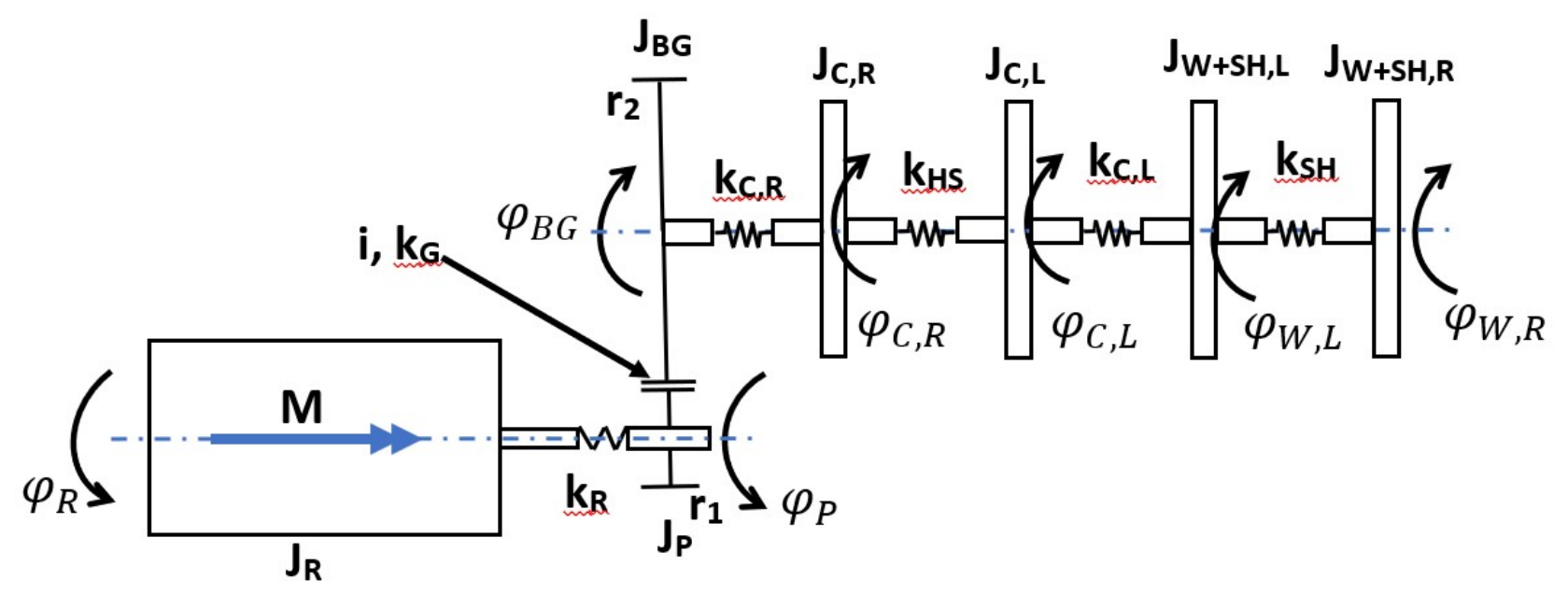

FIGURE 11. Schematic torsion system. 


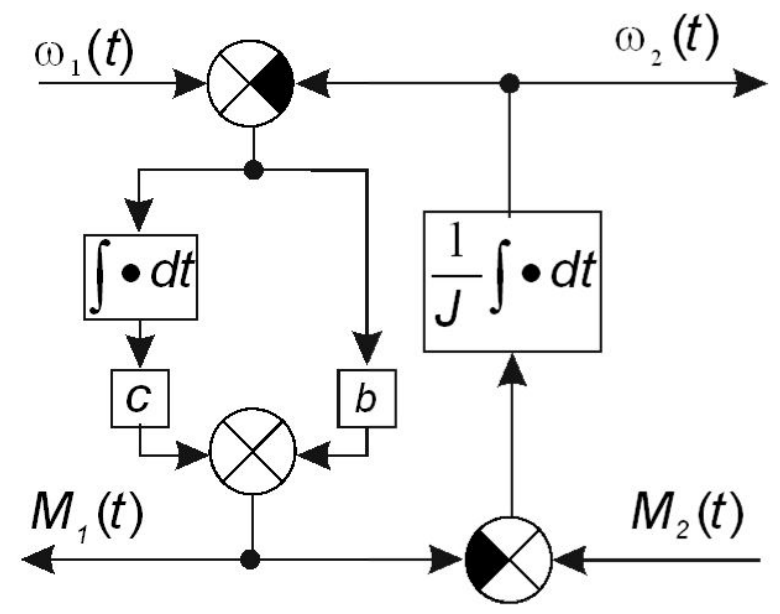

FiguRE 12. Mass and spring mathematical representation [7].

coefficient in the first step and afterwards possibly extend laboratory experiments for students.

Regarding nowadays results from the research oriented towards the torsion oscillations in the railway vehicle traction drives we can say, that these oscillations with significantly high magnitudes can be observed within torques loading particular components of the traction drive even in steady states, not only during transition phenomena. However, such observed torque ripple does not lead to the overloading of these components with respect to their strength, it will have an impact on the damage cumulation and thus on their life parameters. This idea is heading this research to be focused on the investigation of sensitivity of different traction drive's design arrangement on the torsion oscillations and possibilities how to reduce them by means of utilization of modified standard components as couplings or gears.

\section{LIST OF SYMBOLS}

\begin{tabular}{|c|c|}
\hline$f_{x}$ & Coefficient of friction [-], \\
\hline$T_{1}$ & Tangential force $[\mathrm{N}]$, \\
\hline$Q$ & Vertical wheel force $[\mathrm{N}]$, \\
\hline$\mu$ & Coefficient of adhesion [-], \\
\hline$s$ & Wheel slip [\%], \\
\hline$r_{k}$ & Wheel radius $[\mathrm{m}]$ \\
\hline$\omega_{k}$ & Angular speed of a wheel $[\mathrm{rad} / \mathrm{s}]$ \\
\hline$\nu$ & Vehicle velocity $[\mathrm{m} / \mathrm{s}]$ \\
\hline$J_{x}$ & Mass of inertia $\left[\mathrm{kg} \cdot \mathrm{m}^{2}\right]$, \\
\hline$k_{x}$ & Torsion stiffness $\left[\mathrm{N} \cdot \mathrm{m} \cdot \mathrm{rad}^{-1}\right]$, \\
\hline$\varphi_{x}$ & Angle [rad], \\
\hline$r_{1}$ & Pinion rolling radius $[\mathrm{m}]$, \\
\hline$r_{2}$ & Gearwheel rolling radius $[\mathrm{m}]$, \\
\hline$i$ & Gear ratio [-], \\
\hline$M$ & Motor torque, elmag. $[\mathrm{N} \cdot \mathrm{m}]$, \\
\hline
\end{tabular}

$$
\begin{array}{ll}
\omega_{1}, \omega_{2} & \text { Angular speed }\left[\mathrm{rad} \cdot \mathrm{s}^{-1}\right], \\
M_{1}, M_{2} & \text { Torque }[\mathrm{N} \cdot \mathrm{m}] .
\end{array}
$$

\section{ACKNOWLEDGEMENTS}

This research has been realized using the support of The Technology Agency of the Czech Republic, programme National Competence Centres, project \#TN01000026 Josef Bozek National Center of Competence for Surface Transport Vehicles and the support of The Czech Technical University and the related grant No. SGS20/120/OHK2/2T/12.

This support is gratefully acknowledged.

\section{REFERENCES}

[1] N. Bosso, A. Gugliotta, A. Soma. Simulation of narrow gauge railway vehicles and experimental validation by mean of scale tests on roller rig, 2008. Online, ISSN 15729648, https://doi.org/10.1007/s11012-008-9128-4

[2] A. Jaschinski, H. Chollet, S. Iwnicki. The Application of Roller Rigs to Railway Vehicle Dynamics. Vehicle System Dynamics 31, Amsterdam, 1999, https://doi.org/10.1076/vesd.31.5.345.8360

[3] S. Myamlin, J. Kalivoda, L. Neduzha. Testing of Railway Vehicles Using Roller Rigs. Procedia Engineering 2017, 2017, ISSN 1877-7058, https://doi.org/10.1016/j.proeng.2017.04.439.

[4] J. Kalivoda, P. Bauer. Mechatronic bogie for roller rig tests. The Dynamics of Vehicles on Roads and Tracks Proceedings of the 24th Symposium of the International Association for Vehicle System Dynamics, 2016, https://doi.org/10.1201/b21185-96

[5] J. Kolář, M. Dub. Matematické modelování torzní dynamiky pohonu dvojkolí. In Současné problémy v kolejových vozidlech 2017: XXIII. konference s mezinárodní účastí, sborník příspěvků, Pardubice, 2017, p. 195-204, ISBN 978-80-7560-085-1.

[6] O. Polach. Creep forces in simulations of traction vehicles running on adhesion limit. 6th International Conference on Contact Mechanics and Wear of Rail/Wheel Systems, Göthenburg, June 10-13, 2003.

[7] V. Dybala, M. Libenský, B. Šulc, C. Oswald. Slip and Adhesion in a Railway Wheelset Simulink Model Proposed for Detection Driving Conditions Via Neural Networks. Sborník vědeckých prací Vysoké školy báňské - Technické univerzity Ostrava, Řada strojní, Ostrava, 2018, ISSN 1804-0993 (online), https://doi.org/10.22223/tr.2018-1.

[8] V. Dybala. Simulace zvlnění elektromagnetického momentu asynchronního trakčního motoru lokomotivy napájeného ze střídače. Konference Studentské Tvưrčí Činnosti 2019, sborník konference, Praha, 2019, ISBN 978-80-01-06564-8.

[9] V. Dybala. Vliv regulace na frekvenční složení fázových proudů a elektromagnetického momentu při simulování napájení asynchronního motoru ze střídače. Súčasné problémy v kolajových vozidlách - PRORAIL, 2019. Diel I, Žilina, 2019, ISBN 978-80-89276-58-5. 


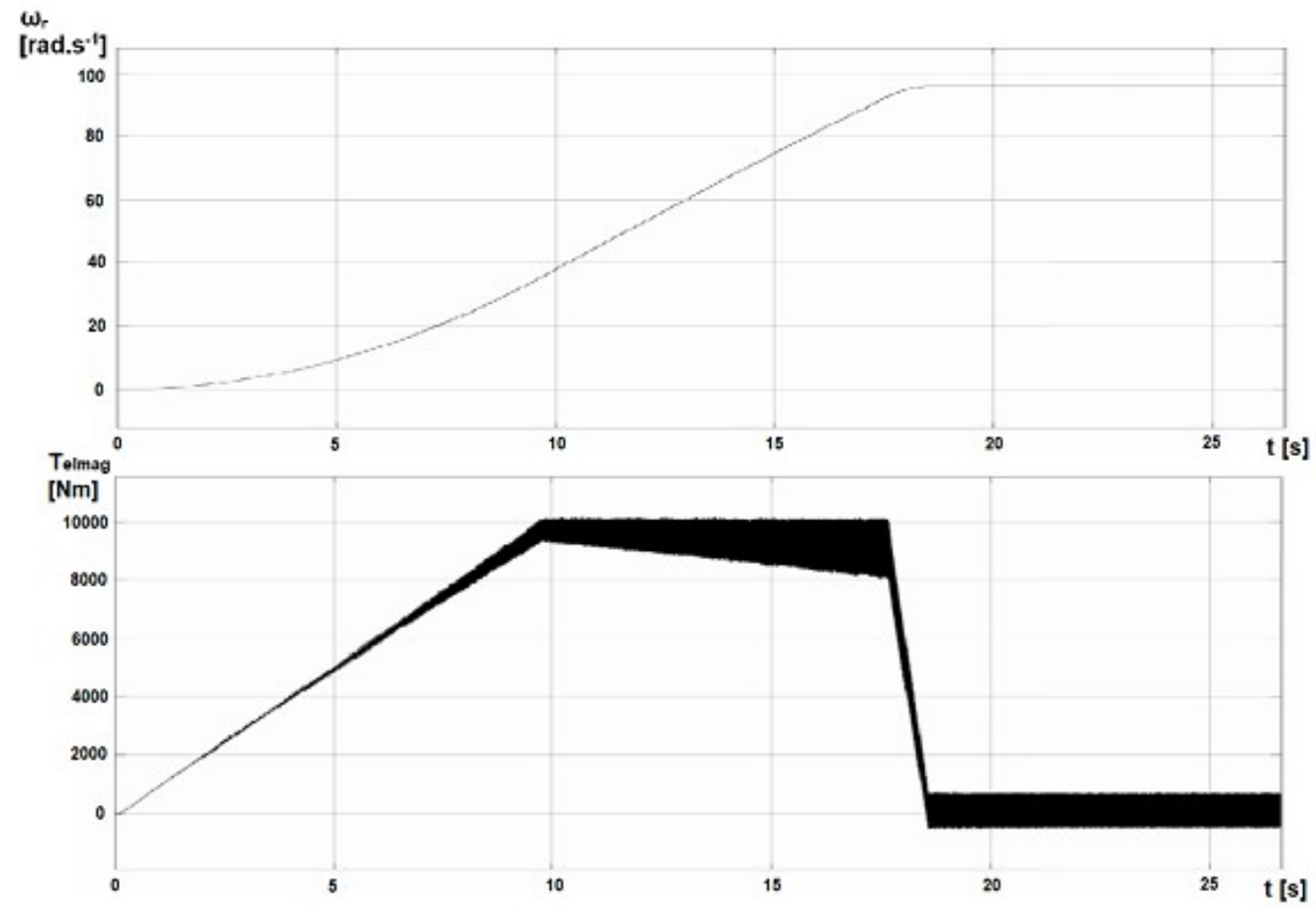

FIGURE 13. Rotor speed and rippled torque of asynchronous motor.
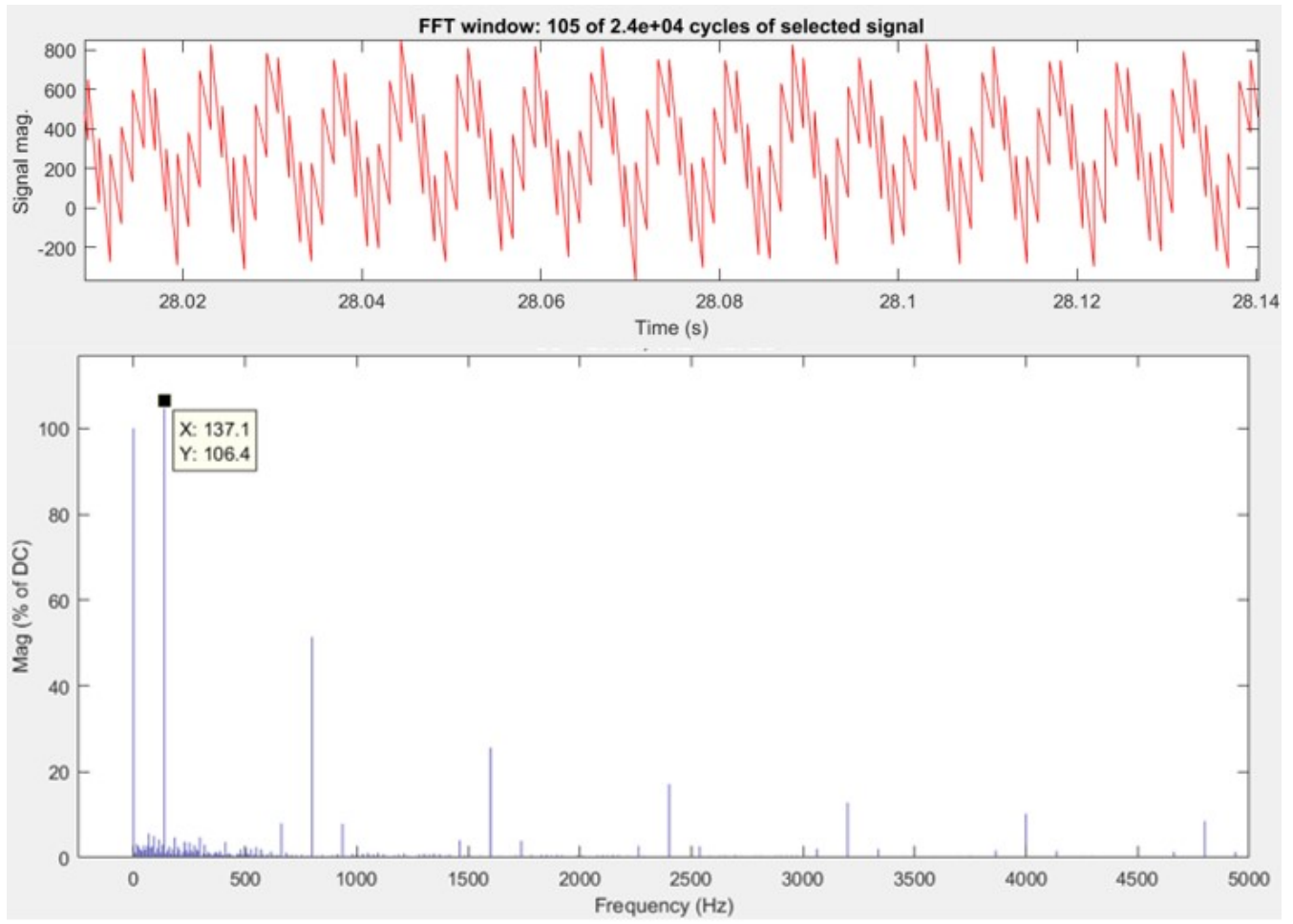

Figure 14. FFT analysis of the electromagnetic torque. 


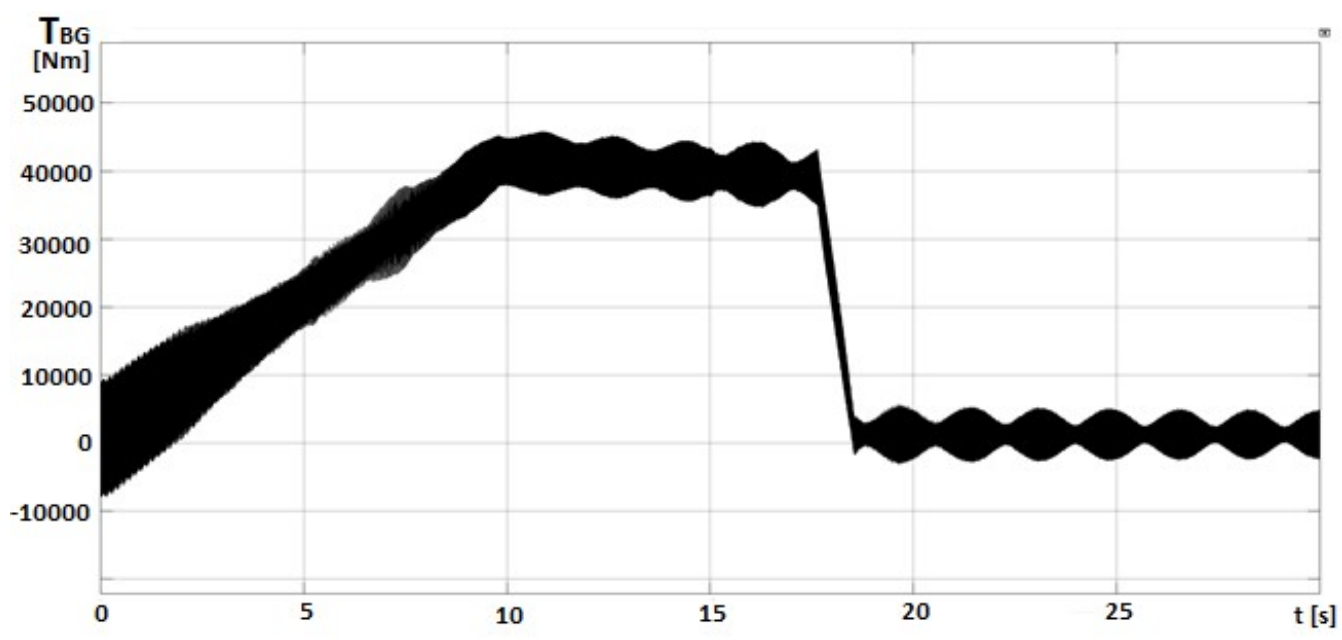

FIGURE 15. Course of gearwheel accelerating torque.
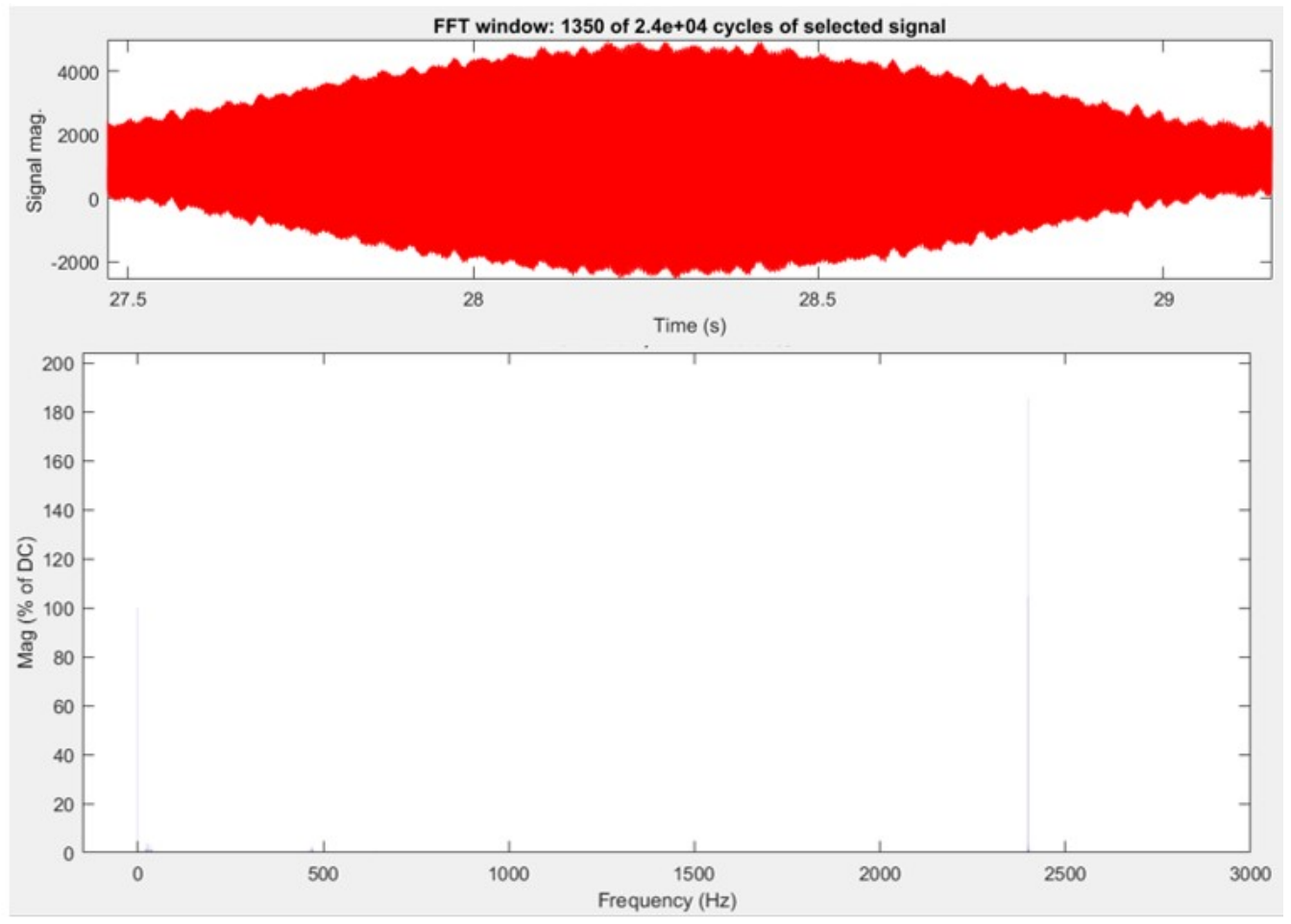

FIGURE 16. FFT analysis of the gearwheel accelerating torque. 